\title{
AMMONIA EXCRETION AND RENAL ENZYMATIC ADAPTATION IN HUMAN SUBJECTS, AS DISCLOSED BY ADMINIS- TRATION OF PRECURSOR AMINO ACIDS 1, 2
}

\author{
By LEONARD L. MADISON AND DONALD W. SELDIN \\ (From The Department of Internal Medicine, The University of Texas Southwestern Medical \\ School, Dallas, Tex.)
}

(Submitted for publication April 15, 1958; accepted July 10, 1958)

Urinary ammonia is produced in renal tubular cells by the deamidation of glutamine and asparagine and the deamination of a variety of amino acids (1-5). Many ammonia-producing enzymes have been identified in mammalian kidney and both their presence and activity appear to vary widely with species (5-14). In the dog, 60 per cent of the urinary ammonia has been attributed to the deamidation of serum glutamine, the remaining 40 per cent apparently originating from amino acid oxidase activity (1). In the human kidney, glutaminase activity is only 0.1 to 0.01 that present in dogs (15). Renal $l$-amino acid oxidase activity is low or absent in most species save the rat (8) and renal $d$-amino acid oxidase varies widely in different species, the activity in the cat being 20 times that in the guinea pig (14).

Recently it has been shown in rats that strong acid loads increase renal ammonia production consequent to adaptation of glutaminase (16-19), glycine oxidase and $l$-amino acid oxidase (16). Increased renal ammonia production and excretion also follows the administration of precursor amino acids; in dogs the administration of a $d l$-alanine, $l$-leucine, glycine, glutamine and $d l$-aspartic acid results in a prompt increase in urinary ammonia excretion (1-4).

It is not known precisely which ammoniaproducing enzymes are present in the human kidney and which of these undergo adaptive change during the administration of strong acid loads. The purposes of this study were threefold: to determine which amino acids are precursors of urinary ammonia, thereby furnishing evidence for the

1 This work was supported by a research grant from The National Institutes of Health, United States Public Health Service and from Smith, Kline and French Foundation.

2 Presented at the meeting of the American Federation for Clinical Research in Atlantic City, May, 1955. presence of various ammonia-producing enzyme systems in the human kidney, to ascertain which of these enzymes show adaptive increase in activity and finally to help define the relationship between ammonia production and ammonia transport by observing the changes in urinary acid excretion during the administration of precursor amino acids.

\section{PROCEDURE}

Five normal male subjects, housed on the metabolic ward and maintained on a diet of constant composition, were given $\mathrm{NH}_{4} \mathrm{Cl}$ loads continuously for from one to five months. One hundred twenty-five studies, each lasting 8 to 10 hours, were performed. To identify the amino acid precursors of urinary ammonia, the subjects were kept on $15 \mathrm{Gm}$. of ammonium chloride until ammonia excretion was constant. Single amino acids (230 to $400 \mathrm{mM}$ ) were then given orally over a 60 to $90 \mathrm{~min}$ ute period and changes in urinary ammonia, $\mathrm{pH}$ and titratable acid (TA) were followed hourly for six to eight hours. These values then were compared to those obtained during a control period of equal duration, performed during the same hours of the day in order to obviate changes related to diurnal variation.

To determine which renal enzyme systems adapt to strong acid loads, subjects were studied under three circumstances : standard diet (SD) plus $5 \mathrm{Gm}$. of $\mathrm{NH}_{4} \mathrm{Cl}$ per day; $\mathrm{SD}$ plus $10 \mathrm{Gm}$. $\mathrm{NH}_{4} \mathrm{Cl}$ per day; and finally, SD plus $15 \mathrm{Gm}$. $\mathrm{NH}_{4} \mathrm{Cl}$ per day. Each level of $\mathrm{NH}_{4} \mathrm{Cl}$ administration was continued from 10 to at least 30 days. When a steady state was attained, as evidenced by a constant urinary ammonia excretion during a fixed six to eight hour period each day (9:00 a.m. to 5:00 p.m.), equimolar amounts $(300 \mathrm{mM})$ of different amino acids were given on different days. ${ }^{3}$ Experiments were performed at no less than three day intervals to allow adequate time for return to a steady state. The amino acids, dissolved in 500 to $1,000 \mathrm{ml}$. of water, were administered orally over a 60 to 90 minute period. Urine specimens were collected hourly under mineral oil in bottles containing phenyl mercuric nitrate as a preservative. Im-

\footnotetext{
${ }^{3}$ On the days of the amino acid loading and control experiments, $\mathrm{NH}_{4} \mathrm{Cl}$ was not administered until after the study was completed. The subjects therefore did not receive $\mathrm{NH}_{4} \mathrm{Cl}$ for 14 hours prior to each experiment.
} 
TABLE I

Mammalian renal enzyme systems capable of ammonia production *

\begin{tabular}{|c|c|c|}
\hline ENZYME & SUBSTRATE & PRODUCTS \\
\hline 1. Glutaminase $(5,12,15)$ & Glutamine & Glutamic acid +ammonia \\
\hline 2. Asparaginase ${ }^{(12)}$ & Asparagine & Aspartic acid +ammonia \\
\hline $\begin{array}{l}\text { 3. D-Amino acid (14) } \\
\text { oxidase }\end{array}$ & $\begin{array}{l}\text { Most D-amino } \\
\text { acids }\end{array}$ & $\begin{array}{l}\text { Corresponding } \\
\alpha \text {-keto acid }+ \text { ammonia }\end{array}$ \\
\hline $\begin{array}{l}\text { 4. L-amino acid }(7,8,14) \\
\text { oxidase }\end{array}$ & $\begin{array}{l}\text { Most L-amino } \\
\text { acids }\end{array}$ & $\begin{array}{l}\text { Corresponding } \\
\alpha \text {-keto acid }+ \text { ammonia }\end{array}$ \\
\hline 5. Glycine oxidase (6) & Glycine & Glyoxylic acid + ammonia \\
\hline $\begin{array}{l}\text { 6. Glutamic acid(14) } \\
\text { dehydrogenase }\end{array}$ & $\begin{array}{c}\text { L-glutamic } \\
\text { acid }\end{array}$ & $\begin{array}{l}\alpha-k e t o g l u t a r i c \\
\text { acid }\end{array}$ \\
\hline \multirow[t]{2}{*}{ 7. Transaminase (13) } & $\underset{\text { acid }}{a . L-a s p a r t i c}+\underset{\text { acid }}{\alpha-k e t o g l u t a r i c}$ & $\underset{\text { acid }}{\text { Oxaloacetic }}+\underset{\text { acid }}{\text { glutamic }}$ \\
\hline & $\begin{array}{c}\text { b.L-alanine }+\alpha \text {-ketoglutaric } \\
\text { acid }\end{array}$ & $\begin{array}{c}\text { Pyruvic } \\
\text { acid }\end{array} \quad+\begin{array}{c}\text { glutamic } \\
\text { acid }\end{array}$ \\
\hline 8. Proline oxidase $(10,14)$ & Proline & L-glutamic acid \\
\hline
\end{tabular}

* Neither the transaminases nor proline oxidae directly produce ammonia but if coupled with gluatamic dehydrogenase, a net production of ammonia occurs. The superscript indicates a reference number.

mediately after voiding, ammonia, $\mathrm{TA}$ and $\mathrm{pH}$ were determined. In 42 experiments titratable acid minus bicarbonate $\left(\mathrm{TA}-\mathrm{HCO}_{8}\right)$ was measured. The values obtained on experimental days, when amino acid was given, at each level of $\mathrm{NH}_{4} \mathrm{Cl}$ administration, were compared to the values obtained on control days at the same level of
$\mathrm{NH}_{4} \mathrm{Cl}$ administration. The net change (experiment minus control) in ammonia excretion, attributable to the administration of each amino acid at each level of $\mathrm{NH}_{4} \mathrm{Cl}$ administration, was thus obtained. The net change in urinary ammonia [or ammonia plus $\left(\mathrm{TA}-\mathrm{HCO}_{3}\right)$ ] after a specific amino acid, while the subject was receiving 5

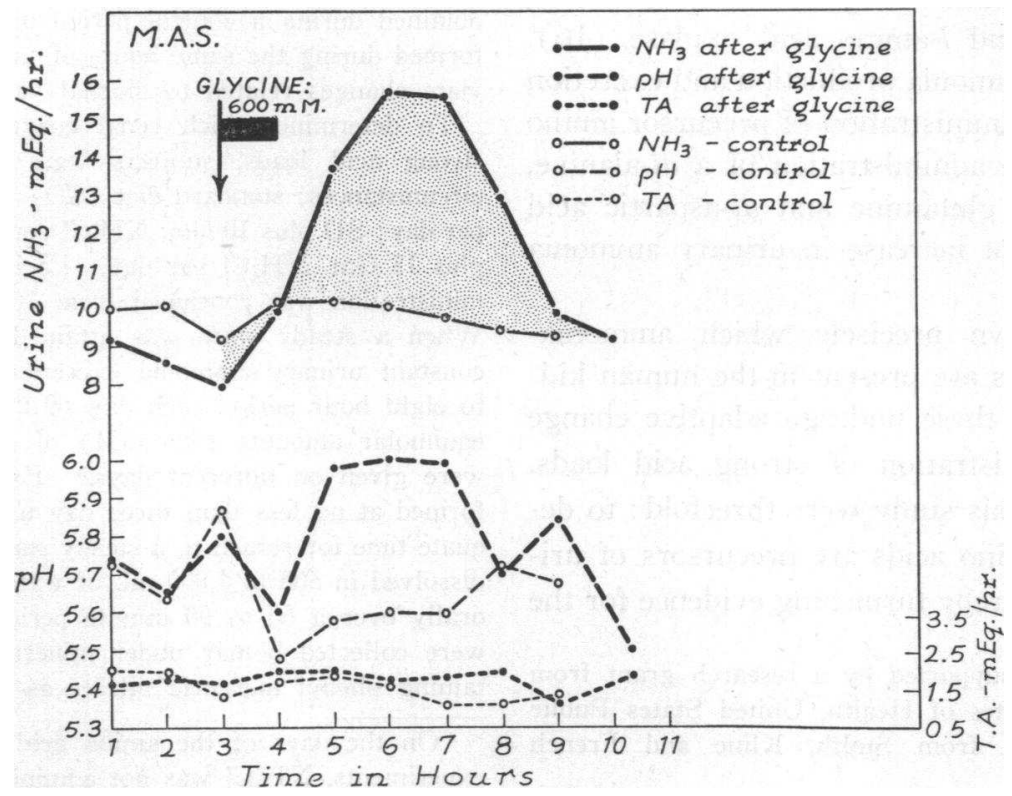

Fig. 1. Effect of Administration of Glycine on Urinary Ammonia Excretion, PH and Titratable AcID 
$\mathrm{Gm} . \mathrm{NH}_{4} \mathrm{Cl}$ per day, was then compared to the net change that occurred when the subject received 10 and then $15 \mathrm{Gm}$. $\mathrm{NH}_{4} \mathrm{Cl}$ per day.

Methods. Urinary ammonia was determined in duplicate by a modification of the microdiffusion method of Conway (20). Urine pH was measured with a Beckman $\mathrm{pH}$ meter using external glass electrodes and corrected to $37.5^{\circ}$ in accord with the findings of Wesson for human urine (21). Urine was titrated to $\mathrm{pH} 7.4$ with $0.1 \mathrm{~N} \mathrm{NaOH}$ to determine titratable acid. TA-HCO was measured by the method of Dawson, Dempsey, Bartter, Leaf and Albright (22). Serum $\mathrm{CO}_{2}$ content was determined manometrically (23). Serum chloride was measured by the method described by Peters and Van Slyke (23); serum sodium and potassium concentrations were determined on the flame photometer (24).

\section{RESULTS}

\section{Identification of ammonia-producing enzyme systems in human kidney by administration of precursor amino acids}

The enzymes producing ammonia from amino acids which have been identified in vitro in mammalian kidney are listed in Table I. A typical experiment showing an augmented ammonia excretion after administration of glycine to a subject stabilized on $15 \mathrm{Gm}$. $\mathrm{NH}_{4} \mathrm{Cl}$ daily is presented diagramatically in Figure 1 . The prompt rise in urinary ammonia excretion lasting four to six hours suggests that glycine oxidase is present in human kidney. The results after the administration of 12 different amino acids suggest that all

TAER: II

Protocols of typical amino acid loading and control studies.*

\begin{tabular}{|c|c|c|c|c|c|c|c|c|c|c|c|c|c|c|}
\hline \multirow{4}{*}{ PREPARATION } & \multicolumn{7}{|c|}{ CONTROL } & \multicolumn{7}{|c|}{ EXPERIMENT } \\
\hline & \multirow{3}{*}{$\begin{array}{l}\text { AMINO } \\
\text { ACID }\end{array}$} & \multirow{3}{*}{$\begin{array}{c}\text { SERUM } \\
\mathrm{CO}_{2} \\
\text { CONTENT } \\
\mathrm{mEq} / \mathrm{L} .\end{array}$} & \multirow{3}{*}{$\begin{array}{c}\text { TIME } \\
\text { minute }\end{array}$} & \multicolumn{4}{|c|}{ URINE } & \multirow{3}{*}{$\begin{array}{l}\text { AMINO } \\
\text { ACID }\end{array}$} & \multirow{3}{*}{$\begin{array}{c}\text { SERUM } \\
\mathrm{CO}_{2} \\
\text { CONTENT } \\
\text { mEQ/L. }\end{array}$} & \multirow{3}{*}{$\begin{array}{c}\text { TIME } \\
\text { minutes }\end{array}$} & \multicolumn{4}{|c|}{ URINE } \\
\hline & & & & \multirow{2}{*}{$\begin{array}{l}\text { VOL. } \\
\text { CC }\end{array}$} & \multirow{2}{*}{ PH } & \multirow{2}{*}{\begin{tabular}{|c|}
$\mathrm{NH}_{3}$ \\
$\mathrm{mEG} / \mathrm{TV}$ \\
\end{tabular}} & \multirow{2}{*}{\begin{tabular}{|c|} 
T.A. \\
$m \in q / T V$ \\
\end{tabular}} & & & & \multirow{2}{*}{$\begin{array}{l}\text { vol. } \\
\text { cc. }\end{array}$} & \multirow{2}{*}{ PH } & $\mathrm{NH}_{3}$ & \multirow{2}{*}{\begin{tabular}{|l|l} 
T.A. \\
mEq/TV
\end{tabular}} \\
\hline & & & & & & & & & & & & & $m E q / T V$ & \\
\hline \multirow{7}{*}{$\begin{array}{l}\text { Standard } \\
\text { diet }+ \\
5 \mathrm{gm} . \\
\mathrm{NH}_{4} \mathrm{Cl} \\
\text { day }\end{array}$} & \multirow[t]{7}{*}{ none } & \multirow[t]{7}{*}{26.2} & 0.60 & 269 & 5.32 & 4.2 & 1.8 & \multirow{7}{*}{$\begin{array}{l}\text { Gly- } \\
\text { cine } \\
400 \mathrm{mM}\end{array}$} & \multirow[t]{7}{*}{27.9} & \multirow{7}{*}{$\begin{array}{c}0-60 \\
60-120 \\
120-180 \\
180-240 \\
240-300 \\
300-360\end{array}$} & 129 & 5.12 & 3.8 & 2.9 \\
\hline & & & $60-120$ & 140 & 5.18 & 3.4 & 1.9 & & & & 118 & 5.77 & 5.2 & 2.4 \\
\hline & & & $120-180$ & 173 & 5.19 & 4.0 & 2.3 & & & & 203 & 6.02 & 6.2 & 2.0 \\
\hline & & & $180-240$ & 239 & 5.38 & 3.1 & 2.0 & & & & 270 & 5.72 & 4.8 & 2.0 \\
\hline & & & $240-300$ & 135 & 5.20 & 3.2 & 1.8 & & & & 297 & 5.53 & 3.5 & 2.4 \\
\hline & & & $|300-360|$ & 195 & 5.23 & 4.3 & 2.2 & & & & 169 & 5.18 & 3.1 & 2.8 \\
\hline & & & & \multicolumn{3}{|c|}{ TOTAL $\overline{22.2}$} & 12.0 & & & & \multicolumn{2}{|c|}{ TOTAL } & 26.6 & 14.5 \\
\hline \multirow{7}{*}{$\begin{array}{c}\text { Standard } \\
\text { diet }+ \\
10 \mathrm{gm} \text {. } \\
\mathrm{NH}_{4} \mathrm{Cl} \\
\text { q.d. }\end{array}$} & \multirow[t]{7}{*}{ none } & \multirow[t]{7}{*}{23.4} & $0-60$ & 314 & 5.19 & 7.3 & 2.7 & GIy- & 24.0 & 0.60 & 105 & 5.18 & 5.9 & 1.3 \\
\hline & & & $60-120$ & 222 & 5.19 & 5.9 & 2.6 & cine & & $60-120$ & 190 & 5.67 & 16.1 & 2.8 \\
\hline & & & $120-180$ & 224 & 5.13 & 6.1 & 2.4 & & & $120-180$ & 160 & 5.95 & 11.6 & 1.4 \\
\hline & & & $180-240$ & 140 & 5.02 & 5.4 & 1.4 & & & $180-240$ & 174 & 6.17 & 9.4 & 1.1 \\
\hline & & & $240-300$ & 170 & 5.12 & 5.5 & 1.7 & & & $240-300$ & 140 & 5.97 & 7.4 & 1.1 \\
\hline & & & $300-360$ & 130 & 5.19 & 4.5 & 1.6 & & & $300-360$ & 140 & 5.58 & 5.8 & 1.8 \\
\hline & & & & & TOTAL & $\overline{34.6}$ & $\overline{12.4}$ & & & & & TOTAL & $\overline{56.2}$ & $\overline{9.5}$ \\
\hline Standard & none & 20.6 & 0.60 & 140 & 5.46 & 11.6 & 2.4 & Gly. & 20.7 & $0-60$ & 55 & 5.78 & 9.1 & 1.4 \\
\hline diet + & & & $60-120$ & 75 & 5.60 & 7.8 & 2.0 & cine & & $60-120$ & 152 & 6.12 & 17.1 & 2.2 \\
\hline $\mathrm{NH}_{4} \mathrm{Cl}$ & & & $120-180$ & 120 & 5.55 & 9.2 & 1.2 & & & $120-180$ & 68 & 6.08 & 7.3 & 0.7 \\
\hline q.d. & & & $180-240$ & 110 & 5.45 & 8.9 & 2.1 & & & $180-240$ & 226 & 6.15 & 30.5 & 1.7 \\
\hline & & & $240-300$ & 112 & 5.49 & 9.7 & 1.3 & & & $240-300$ & 499 & 6.42 & 13.7 & 1.8 \\
\hline & & & $300-360$ & 87 & 5.60 & 8.7 & 1.4 & & & $300-360$ & 226 & 6.18 & 19.4 & 1.4 \\
\hline & & & & & TOTAL & $\overline{55.9}$ & $\overline{10.4}$ & & & & & TOTAL & $\overline{97.1}$ & $\overline{9.2}$ \\
\hline
\end{tabular}

* TV refers to total urine volume. 


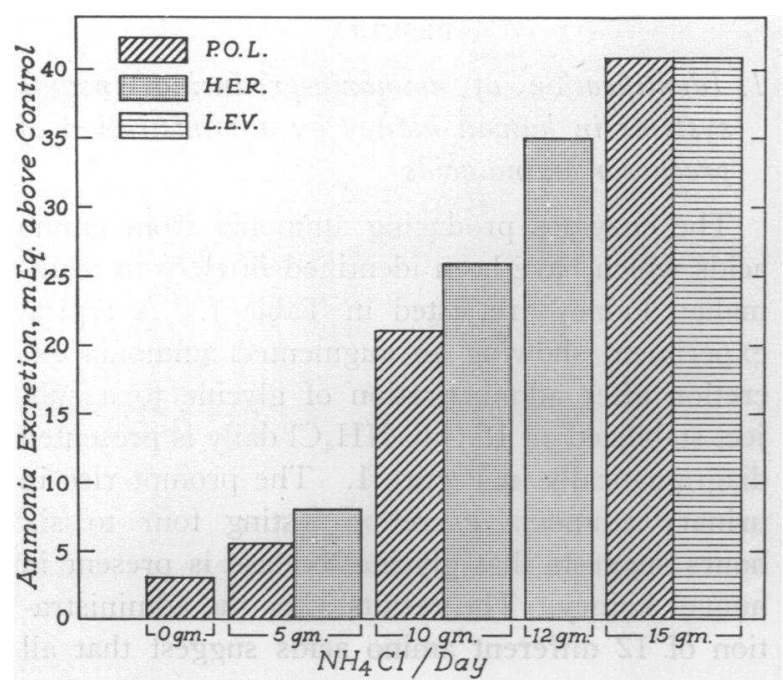

Fig. 2. Effect of Glycine Administration on Net Ammonia Excretion in Three Subjects During Stepwise Increase in the Magnitude of the Chronic Ammonium ChLORIDE LoAds

of the enzyme systems listed in Table I are present in human kidney. The administration of $l$-lysine did not increase ammonia excretion in keeping with similar findings in dogs (2).
2. Adaptation of ammonia-producing enzymes in the human kidney during the chronic administration of ammonium chloride loads

The protocols from a typical series of experiments performed to determine whether enzyme adaptation occurred are shown in Table II. Net ammonia excretion (experiment minus control) progressively increased from 4.2 to 21.6 to 41 mEq. following the administration of $400 \mathrm{mM}$ of glycine to a subject chronically maintained on 5 , then 10 and finally $15 \mathrm{Gm}$. of $\mathrm{NH}_{4} \mathrm{Cl}$ per day. Data from three subjects showing the increasing magnitude of net ammonia excretion following the administration of $400 \mathrm{mM}$ of glycine at different levels of NH.Cl intake are shown in Figure 2.

Typical examples of the results of experiments in two other subjects performed in a similar manner to determine whether or not adaptation of glutaminase, asparaginase, $d$-amino acid oxidase and $l$-amino acid oxidase occurred are shown in Figures 3 and 4.

The mean increase in net ammonia excretion for the five subjects following the administration of this group of precursor amino acids (glycine,

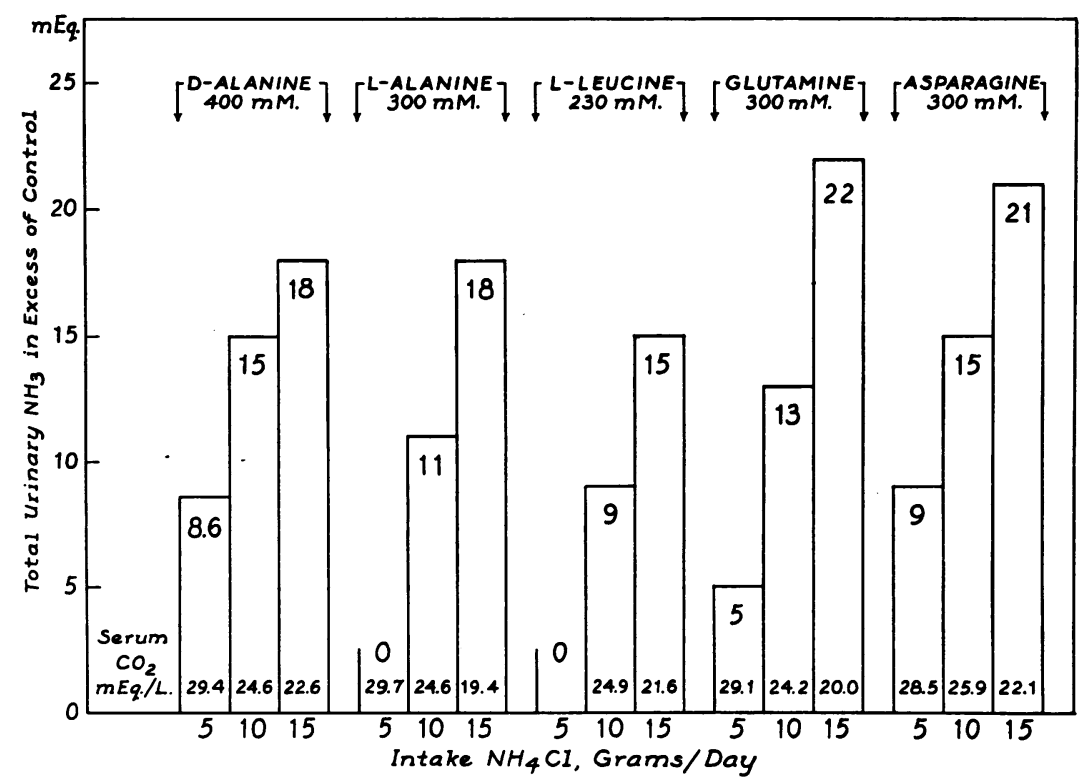

Fig. 3. Effect of Different Amino Acids and Amino Acid Amides on Net Urinary Ammonia Excretion Following Stepwise Increase in the Magnitude of the Chronic Ammonium Chloride Load

The numbers in the columns refer to the net increase in urinary ammonia after the substrate load. 


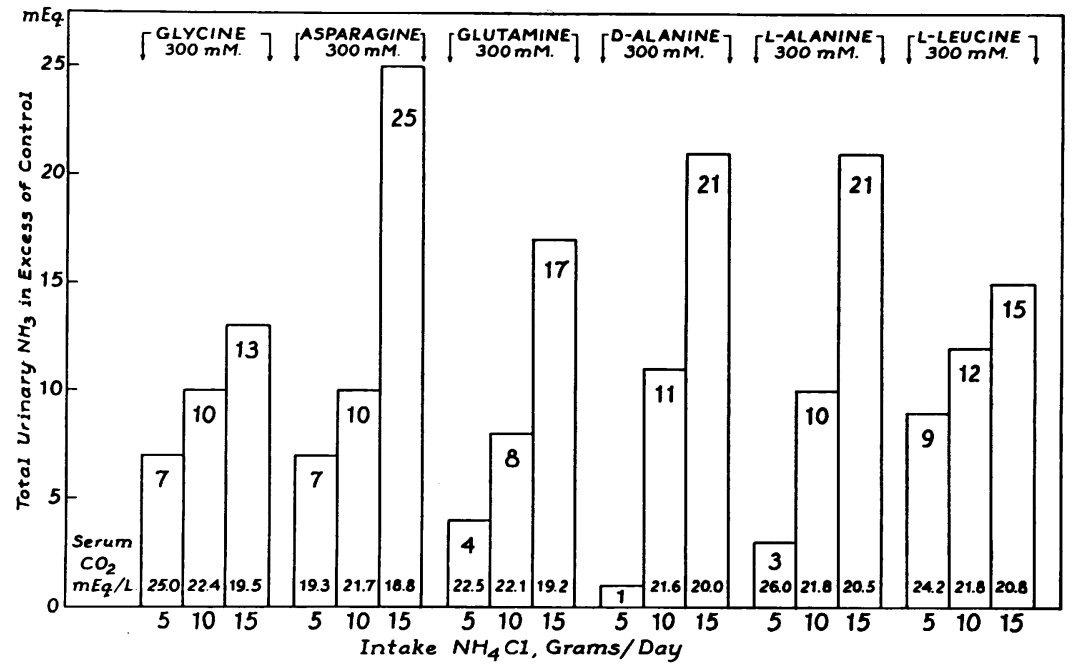

Fig. 4. Effect of Different Amino Acids and Amino Acid Amides on Net Urinary Ammonia Excretion Following Stepwise Increase in the Magnitude of the Chronic Ammonium Chloride Load

The numbers in the columns refer to the net increase in urinary ammonia after the substrate load.

asparagine, glutamine, $l$-alanine, $d$-alanine and $l$-leucine $)$ increased significantly $(\mathrm{p}=<0.01)$ from 4.8 to 12.2 to $20.6 \mathrm{mEq}$. as the chronic maintenance dose of $\mathrm{NH}_{4} \mathrm{Cl}$ was increased from 5 to 10 to $15 \mathrm{Gm}$. a day.
By contrast, the administration of glutamate, aspartate or proline resulted in only a small relatively fixed net increment in ammonia excretion ( 2 to $7 \mathrm{mEq}$.) despite increasing magnitude of the ammonium chloride loads (Figure 5). To be

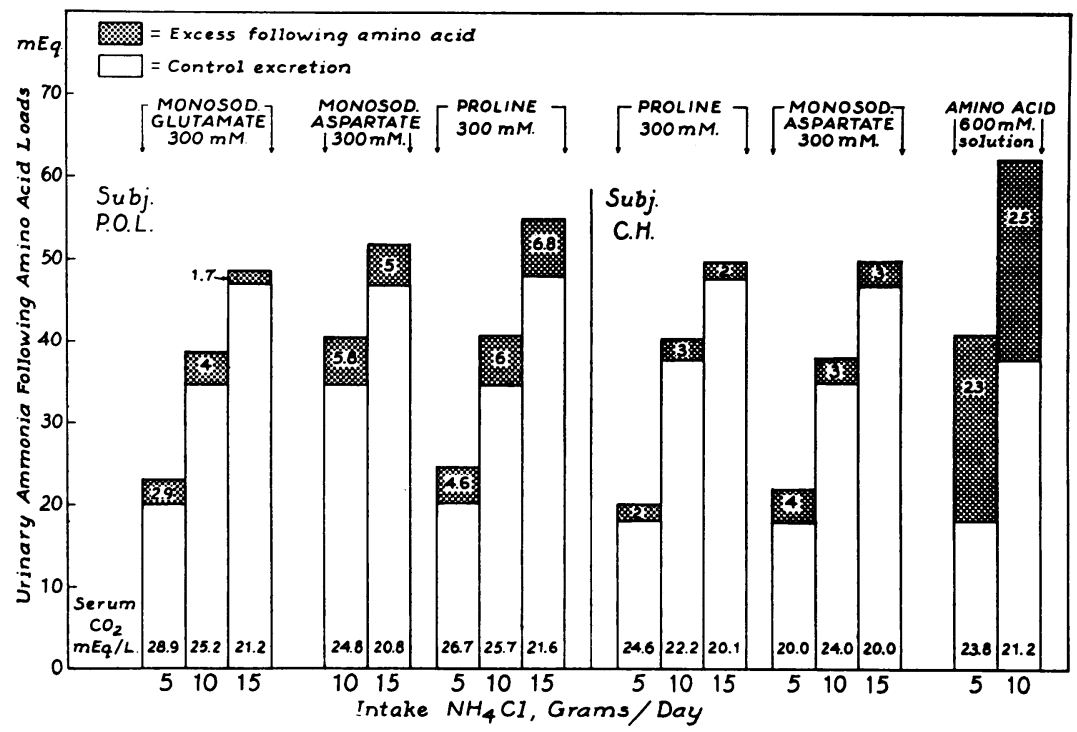

Fig. 5. Effect of Glutamate, Aspartate and Proline on Net Urinary Ammonia Excretion Following Stepwise Increase in the Magnitude of the Chronic Ammonium Chloride load

The numbers in the columns refer to the net increase in urinary ammonia after the substrate load. 
TABLE III

Effect of amino acid administration on total acid excretion during chronic $\mathrm{NH}_{4} \mathrm{Cl}$

loads*

\begin{tabular}{|c|c|c|c|c|c|c|}
\hline \multirow[b]{2}{*}{$\begin{array}{l}\text { TIME } \\
\text { min. }\end{array}$} & \multirow{2}{*}{$\begin{array}{l}\text { URINE } \\
\text { VOL. } \\
m \mathrm{l} . / \mathrm{min} \text {. }\end{array}$} & \multirow[b]{2}{*}{$\begin{array}{c}\text { UR INE } \\
\text { PH }\end{array}$} & \multicolumn{4}{|c|}{ RATE OF EXCRETION } \\
\hline & & & $\begin{array}{c}\mathrm{NH}_{3} \\
\mu E \mathrm{q}_{\text {min }}\end{array}$ & $\begin{array}{c}\text { TA } \\
\mu E q / m i n .\end{array}$ & $\begin{array}{r}\mathrm{TA}-\mathrm{HCO}_{3} \\
\mu \mathrm{E} q / \mathrm{min} . \\
\end{array}$ & $\begin{array}{c}\mathrm{NH}_{3}+\left(\mathrm{TA}-\mathrm{HCO}_{3}\right) \\
\mu \mathrm{Eq} / \mathrm{min} .\end{array}$ \\
\hline $\begin{array}{c}0-60 \\
60-120 \\
120-200\end{array}$ & $\begin{array}{l}3.7 \\
2.7\end{array}$ & $\begin{array}{l}5.68 \\
5.52\end{array}$ & $\begin{array}{c}87 \\
84 \\
\mid \text { - a I an ine }\end{array}$ & $\begin{array}{c}14 \\
15 \\
300 \mathrm{mM}\end{array}$ & $\begin{array}{l}12 \\
14\end{array}$ & $\begin{array}{l}99 \\
98\end{array}$ \\
\hline $\begin{array}{l}120-240 \\
240-360\end{array}$ & $\begin{array}{l}6.5 \\
3.4\end{array}$ & $\begin{array}{l}5.77 \\
6.04\end{array}$ & $\begin{array}{l}159 \\
193\end{array}$ & $\begin{array}{l}27 \\
12\end{array}$ & $\begin{array}{r}23 \\
9\end{array}$ & $\begin{array}{l}182 \\
202\end{array}$ \\
\hline $\begin{array}{c}0-60 \\
60-120 \\
120-200 \\
120-240 \\
240-360 \\
360-480\end{array}$ & $\begin{array}{l}3.2 \\
4.9 \\
1500 \\
5.1 \\
4.0 \\
3.5\end{array}$ & $\begin{array}{c}5.56 \\
5.34 \\
\dot{2} \operatorname{amino} \\
5.65 \\
5.90 \\
5.73\end{array}$ & $\begin{array}{c}84 \\
114 \\
\text { acid sol } \\
164 \\
200 \\
156\end{array}$ & \begin{tabular}{|}
13 \\
21 \\
ut i on 1600 \\
23 \\
24 \\
17
\end{tabular} & \begin{tabular}{|}
$\left|\begin{array}{|c|}11 \\
19\end{array}\right|$ \\
OmM )-12.5c \\
22 \\
21 \\
15
\end{tabular} & 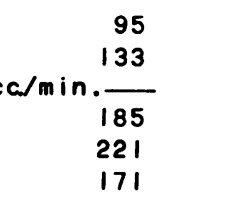 \\
\hline $\begin{array}{c}0-60 \\
60-120 \\
120-200 \\
120-240 \\
240-360 \\
360-480\end{array}$ & $\begin{array}{l}1.2 \\
1.1 \\
2.7 \\
7.0 \\
1.7\end{array}$ & \begin{tabular}{|l|}
5.80 \\
5.85
\end{tabular} & $\begin{array}{r}115 \\
126 \\
-1-\text { aspara } \\
215 \\
253 \\
136\end{array}$ & $\begin{array}{c}16 \\
17 \\
\text { gine } 300 \\
26 \\
21 \\
18\end{array}$ & 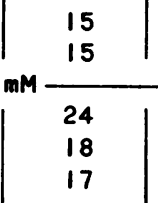 & $\begin{array}{l}130 \\
141 \\
239 \\
273 \\
153\end{array}$ \\
\hline $\begin{array}{c}0-60 \\
60-120 \\
120-200 \\
120-240 \\
240-360 \\
360-480\end{array}$ & $\begin{array}{l}3.8 \\
6.0 \\
8.0\end{array}$ & $\begin{array}{l}5.89 \\
6.10 \\
5.80\end{array}$ & $\begin{array}{l}135 \\
96 \\
0-\text { a I an } \\
177 \\
234 \\
155\end{array}$ & ine $\begin{array}{c}29 \\
20 \\
300 \mathrm{ml} \\
36 \\
16 \\
44\end{array}$ & $\begin{array}{l}20 \\
18 \\
23 \\
15 \\
43\end{array}$ & $\begin{array}{l}155 \\
114 \\
200 \\
249 \\
198\end{array}$ \\
\hline
\end{tabular}

* Total acid excretion $\left[\mathrm{NH}_{3}+\left(\mathrm{TA}-\mathrm{HCO}_{3}\right)\right]$ is increased in each instance.

certain that a small but significant increase did not occur, an amino acid solution containing 600 $\mathrm{mM}$ of a mixture of amino acids composed for the most part of glutamic acid, proline and aspartic acid was infused at two different levels of ammonium chloride administration. Total ammonia excretion was greater, but again there was no progressive net increase in ammonia excretion with increasing magnitude of the ammonium chloride load (Figure 5, last two columns).

\section{The effect of increased ammonia production} following amino acid administration on total urinary acid excretion

The invariable and significant augmentation of total acid excretion $\left[\mathrm{NH}_{3}\right.$ plus $\left.\left(\mathrm{TA}-\mathrm{HCO}_{3}\right)\right]$ after amino acid loads is indicated by the four typical protocols listed in Table III.

4 Approximately $25 \mathrm{mM}$ each of serine, valine, phenylalanine and threonine were also present.

\section{Relationship between ammonia production and transport}

The administration of precursor amino acid to subjects maintained on a chronic strong acid load invariably causes a rise in urine $\mathrm{pH}$ as $\mathrm{NH}_{3}$ excretion increases. Typical changes in urine $\mathrm{pH}$ and ammonia excretion which occured in one subject are shown in Figure 6. Mean ammonia excretion for the five subjects studied increased significantly $(p=<0.001$ ) from 6.1 to $10.1 \mathrm{mEq}$. per hour concomitant with a significant rise $(p=$ $<0.001$ ) in mean urine $\mathrm{pH}$ from 5.60 to 6.12 . Similar increases in urine $\mathrm{pH}$ following amino acid loads have been found in dogs by some (25) but not by others (2).

When subjects continuously received $\mathrm{NH}_{4} \mathrm{Cl}$ it was noted that, after a steady state was attained at each level of $\mathrm{NH}_{4} \mathrm{Cl}$ administration, urinary ammonia increased as the magnitude of the chronic 
acid load increased but urinary $\mathrm{pH}$, instead of falling, rose progressively (Figure 7). In order to determine whether or not, during chronic acid loads, urinary ammonia excretion is independent of changes in urine $\mathrm{pH}$, acute alkalosis was produced by the infusion of sodium bicarbonate during a time when ammonia production was being stimulated toward maximal levels. One subject (M. A. S.) was maintained on $15 \mathrm{Gm}$. of $\mathrm{NH}_{4} \mathrm{Cl}$ a day for about 30 days. At this time $600 \mathrm{mM}$ of glycine was administered, resulting in an increase in ammonia excretion from 8 to $15.6 \mathrm{mEq}$. per hour. The identical experiment was repeated but in addition during the second study $250 \mathrm{mM}$ of $\mathrm{NaHCO}_{3}$ was infused producing an acute alkalosis, serum $\mathrm{CO}_{2}$ rising from 22 to $35 \mathrm{mEq}$. per L. and urine $\mathrm{pH}$ from 5.59 to 7.63 . The expected increase in ammonia excretion incident to the anticipated increase in ammonia production was not torthcoming. Instead urinary ammonia excretion fell progressively from 8.2 to $2.4 \mathrm{mEq}$. per hour. These experiments are compared in Figure 8.

\section{DISCUSSION}

The administration of an amino acid during the chronic maintenance of $\mathrm{NH}_{4} \mathrm{Cl}$ loads of increasing magnitude results in three types of response: 1 ) $l$-Lysine and presumably similar diaminomonocarboxylic acids (2) elicit no increase in urinary ammonia excretion; 2) glutamate, aspartate and proline result in a small, constant increment in ammonia excretion; 3) glycine, glutamine, asparagine, $l$-alanine, $l$-leucine and $d$-alanine each progressively augment ammonia excretion in stepwise fashion paralleling the increase in ammonium chloride load. These data indicate that certain amino acids augment ammonia excretion, and also in the light of certain theoretical considerations help to identify the character of the renal enzymatic adaptation.

These experiments, designed to determine in vivo adaptation of the renal ammonia-producing enzymes, were based on the premise that at any given substrate concentration more end-product will be formed per unit time if more enzyme is present. If the chronic administration of strong acid loads results in an increase in renal tubular

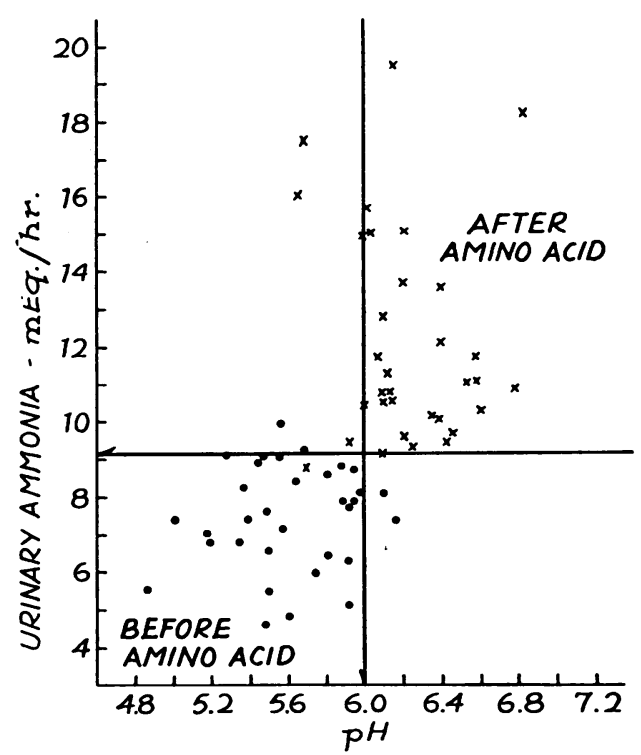

Fig. 6. Relationship Between Urine PH AND Ammonia Excretion Before and After the Administration of Amino Acid Loads

The solid dot represents the peak ammonia excretion with associated urine $\mathrm{pH}$ prior to amino acid administration and the cross, the peak urinary ammonia and associated urine $\mathrm{pH}$ after amino acid administration. In each instance ammonia excretion and urine $\mathrm{pH}$ increased after amino acid administration. The horizontal and vertical lines are arbitrarily drawn to maximally separate the values before and after amino acid loading. In this subject mean ammonia excretion increased from 7.5 to 12.2 $\mathrm{mEq}$. per hour despite a rise in mean urine $\mathrm{pH}$ from $\mathbf{5 . 6}$ to 6.2 .

enzyme activity, ${ }^{5}$ then the renal production of ammonia following the same quantity of amino acid substrate before and after enzyme adaptation should differ quantitatively. After enzyme adaptation, the identical substrate load should result in an increased ammonia production ascribable to the increased enzyme activity. This hypothesis is schematically represented in Figure 9.

Before enzyme adaptation, as substrate concentration is increased from $\mathrm{S}^{1}$, the plasma concentration before the administration of the fixed single amino acid load, to $S^{2}$, the plasma concentration after the substrate load, ammonia production per unit time by the nonadapted enzyme $\mathrm{E}^{\mathbf{1}}$ increases from $\mathrm{P}^{1}$ to $\mathrm{P}^{2}$. The net increase in ammonia pro-

5 The increased enzyme activity that attends the adaptive process may be the result of either increased enzyme concentration, increased enzyme activator or decreased enzyme inhibitor. 


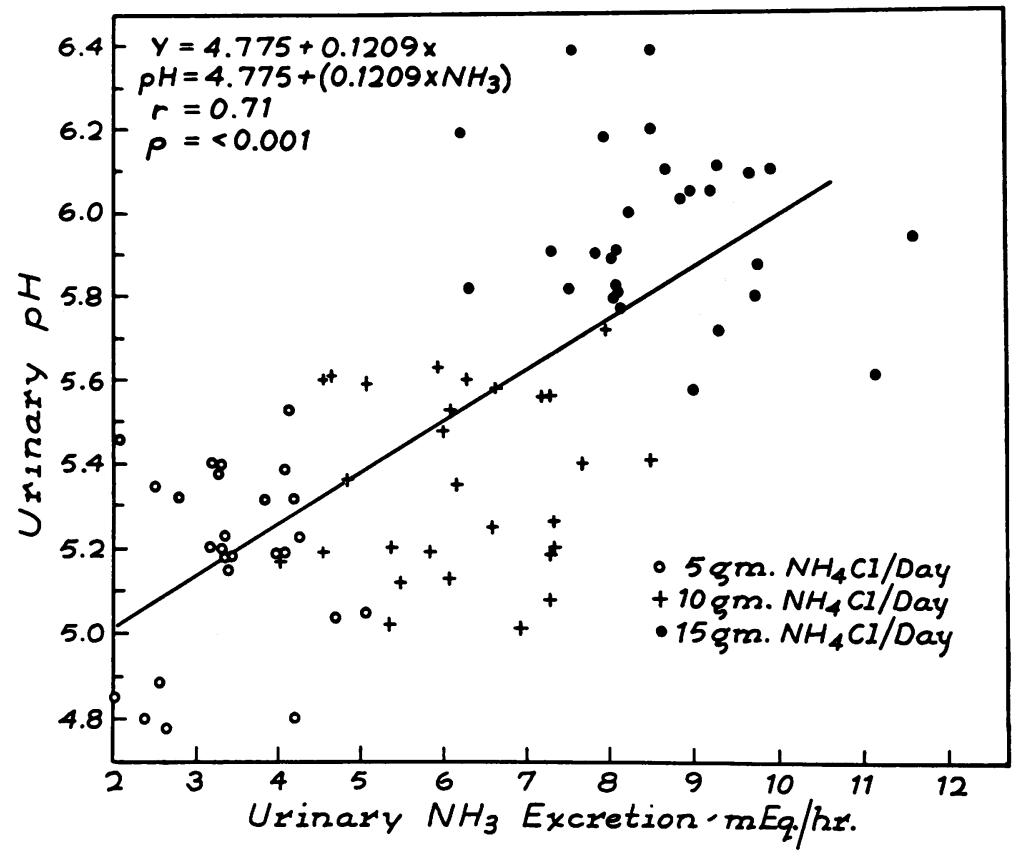

Fig. 7. Relationship Between Ammonia Excretion and Urinary pH During Chronic $\mathrm{NH}_{4} \mathrm{Cl}$ Loads

As the chronic acid load was increased in stepwise fashion mean urinary ammonia excretion increased from 3.4 to 6.2 to $8.6 \mathrm{mEq}$. per hour. Urinary $\mathrm{pH}$ also increased progressively from 5.18 to 5.39 and reached 5.96 as the $\mathrm{NH}_{4} \mathrm{Cl}$ load was increased from 5 to 10 to $15 \mathrm{Gm}$. per day.

duction ascribable to the effect of the substrate load on enzyme $E^{1}$ is therefore equal to ( $P^{2}$ minus $\mathrm{P}^{1}$ ). If the activity of the ammonia producing enzyme increases from $\mathrm{E}^{1}$ to $\mathrm{E}^{2}$ after the administration of a strong acid load, then the administration of the same quantity of substrate should result in a greater net increase in ammonia production ( $\mathrm{P}^{4}$ minus $\mathrm{P}^{3}$ ) compared to the unadapted enzyme $\left(E^{1}\right)$. Finally, since the magnitude of the net increase in ammonia production after a substrate load is dependent on the enzymatic activity, the ratio $\left(\mathrm{P}^{4}\right.$ minus $\left.\mathrm{P}^{3}\right) /\left(\mathrm{P}^{2}\right.$ minus $\left.\mathrm{P}^{1}\right)$, should reflect the magnitude of change in enzyme activity from $\mathrm{E}^{1}$ to $\mathrm{E}^{2}$.

In applying this hypothesis to in vivo experiments two assumptions were made:

1) The quantity of amino acid substrate delivered to the tubular enzymes per unit time after an identical substrate load does not progressively increase as the magnitude of the ammonium chloride load is increased from 5 to $15 \mathrm{Gm}$. per day. The renal hemodynamic changes that accompany the administration of ammonium chloride loads indicate a decrease in glomerular filtration rate and renal plasma flow (27). A decrease in the delivery of substrate with increasing $\mathrm{NH}_{4} \mathrm{Cl}$ loads would not interfere with the interpretataions since it would tend to minimize, not maximize, the magnitude of the adaptive process. Since the amino acids were administered orally, traversing the liver prior to entry into the systemic circulation, the plasma concentration is, in part, dependent upon the fate of the amino acid in the liver. It is possible that as the magnitude of the $\mathrm{NH}_{4} \mathrm{Cl}$ load was progressively increased, the larger doses may have increasingly loaded the hepatic urea-synthesizing mechanism, thereby permitting larger amounts of amino acid to escape to the systemic circulation. Were this true, then the increasing ammonia excretion following identical oral substrate loads administered at high levels of $\mathrm{NH}_{4} \mathrm{Cl}$ intake, could represent increasing substrate reaching the kidney rather than enzyme adaptation; this seems unlikely for two reasons. One, the subjects did not 
receive any $\mathrm{NH}_{4} \mathrm{Cl}$ for 14 hours prior to control or amino acid loading studies (see Procedure). Moreover when $600 \mathrm{mM}$ of asparagine was administered to a subject maintained on $5 \mathrm{Gm}$. of $\mathrm{NH}_{4} \mathrm{Cl}$ per day, net ammonia excretion was 15 $\mathrm{mEq}$. By contrast when maintained on $15 \mathrm{Gm}$. of $\mathrm{NH}_{4} \mathrm{Cl}$, the same subject's net ammonia excretion after only $300 \mathrm{mM}$ of asparagine was $25 \mathrm{mEq}$. In another subject maintained on $5 \mathrm{Gm}$. of $\mathrm{NH}_{4} \mathrm{Cl}$, net ammonia excretion after $600 \mathrm{mM}$ of glycine was $14 \mathrm{mEq}$. When maintained on 10 and 15 $\mathrm{Gm}$. of $\mathrm{NH}_{4} \mathrm{Cl}$ an intake of only $400 \mathrm{mM}$ of glycine resulted in a net ammonia excretion of 22 and $41 \mathrm{mEq}$., respectively.

2) It must also be assumed in these experiments that ammonia excretion quantitatively reflects the magnitude of renal ammonia production. Ammonia produced within the tubular cells has three different fates, i.e., excretion into tubular urine; diffusion into renal venous blood; and intracellular utilization. Despite these alternative pathways, the present analysis is not adversely affected since the bulk of the ammonia formed in acidotic animals is excreted $(1,25)$ and, therefore, although not equal to, reflects quantitatively ammonia production. In support of this assumption are other studies from this laboratory in rats given increas-

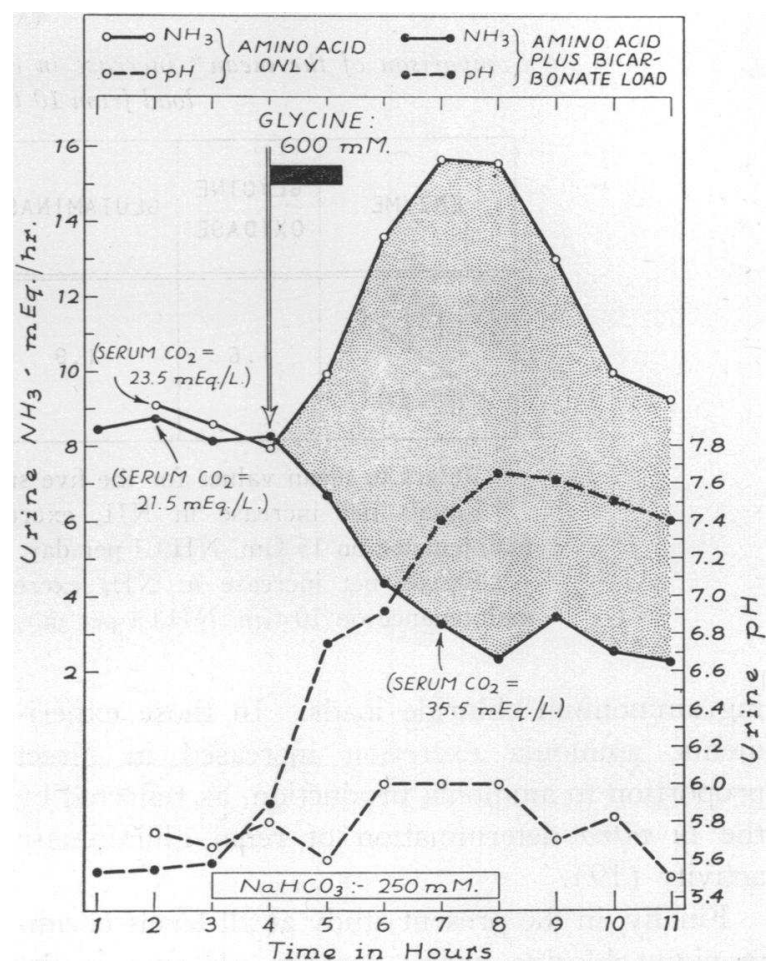

Fig. 8. Effect of Acute Alkalosis on Urinary Ammonium Excretion After Amino Acid AdminisTRATION

See text for details.
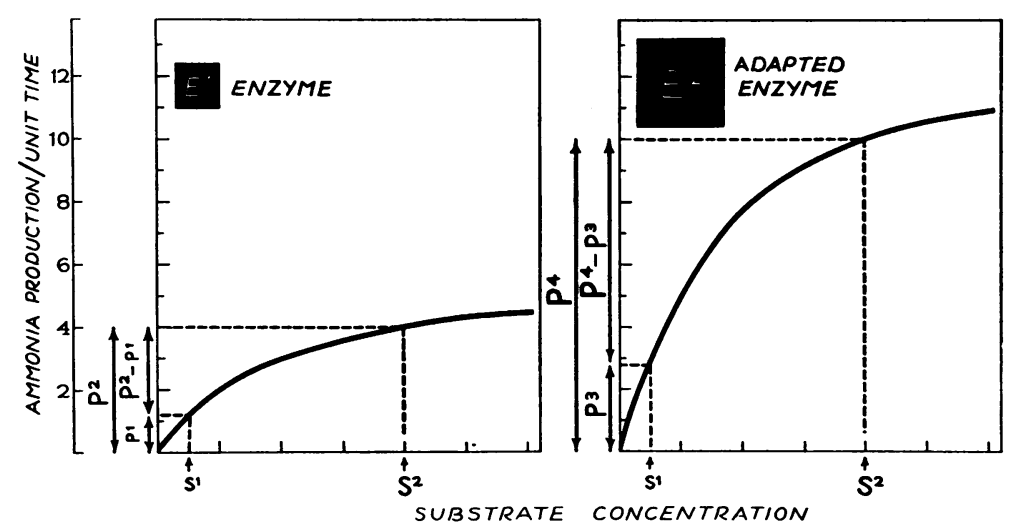

Fig. 9. Effect of Enzyme Adaptation on the Magnitude of Ammonia Production Following a Fixed Substrate Load

The conditions before enzyme adaptation $\left(E^{1}\right)$ are shown on the left and after enzyme adaptation $\left(E^{2}\right)$ on the right. Substrate concentration in arbitrary units is plotted along the abscissa and the rate of reaction, in arbitrary units of end-product formed per unit time, along the ordinate. The curved line in each panel describes the effect of increasing substrate concentration on the rate of reaction. The steeper curve on the right is the result of the increased activity of the adapted enzyme (26). See text for details. 
TABLE IV

Comparison of the mean * increase in ensyme activity after increasing the $\mathrm{NH}_{4} \mathrm{Cl}$ load from 10 to $15 \mathrm{Gm}$. per day

\begin{tabular}{|c|c|c|c|c|c|}
\hline ENZYME & $\begin{array}{l}\text { GLYCINE } \\
\text { ÓXIDASE }\end{array}$ & GLUTAMINASE & ASPARAGINASE & $\begin{array}{l}\ell-A M I N O \\
\text { ACID } \\
\text { OXIDASE }\end{array}$ & $\begin{array}{l}d-A M I N O \\
\text { ACID } \\
\text { OXIDASE }\end{array}$ \\
\hline & 1.6 & 1.9 & 1.9 & 1.9 & 1.5 \\
\hline
\end{tabular}

* Refers to mean values for the five subjects.

$\dagger$ Equals net increase in $\mathrm{NH}_{\mathrm{z}}$ excretion after substrate load during chronic maintenance on $15 \mathrm{Gm}$. $\mathrm{NH}_{4} \mathrm{Cl}$ per day.

¥ Equals net increase in $\mathrm{NH}_{\mathrm{s}}$ excretion after substrate loads during chronic maintenance on $10 \mathrm{Gm}$. $\mathrm{NH}_{4} \mathrm{Cl}$ per day.

ing ammonium chloride ioads. In those experiments, ammonia excretion increased in direct proportion to ammonia production, as reflected by the in vitro determination of renal glutaminase activity (19).

Finally, in the present study at all levels of ammonium chloride intake, urinary $\mathrm{pH}$ was in the acid range. Moreover, mean urinary $\mathrm{pH}$ increased as the magnitude of the chronic ammonium chloride load was increased (Figure 7). With such changes in urinary $\mathrm{pH}$, a progressively increasing net ammonia excretion in response to a fixed substrate load cannot be ascribed to improved conditions for transport.

In the light of these considerations, the data indicate that glycine oxidase, glutaminase, asparaginase, $l$-amino acid oxidase and $d$-amino acid oxidase show adaptive increases in the human kidney following the chronic administration of strong acids.

Although the data do not permit the measurement of the magnitude of the adaptive response of each of these five enzyme systems in absolute terms, the relative increase in enzyme activity as the size of the $\mathrm{NH}_{4} \mathrm{Cl}$ load is increased can be estimated. Since the magnitude of the net increase in ammonia production after a substrate load is dependent on the enzyme activity, then the ratio, net increase in ammonia production after substrate during maintenance on $15 \mathrm{Gm} . \mathrm{NH}_{4} \mathrm{Cl}$ per day/ net increase in ammonia production after identical substrate load during maintenance on $10 \mathrm{Gm}$. of $\mathrm{NH}_{4} \mathrm{Cl}$ per day, should reflect the magnitude of increase in enzyme activity as the chronic load of $\mathrm{NH}_{4} \mathrm{Cl}$ was increased from 10 to $15 \mathrm{Gm}$. per day. ${ }^{\circ}$ These changes for each of the enzymes which undergo adaptive increase are compared in Table IV. The ratio of change for this group of enzymes varied from 1.5 to 1.9 , indicating a one and a half to twofold increase in enzyme activity as the chronic $\mathrm{NH}_{4} \mathrm{Cl}$ load was increased from 10 to $15 \mathrm{Gm}$. per day. This similarity in response suggests a symmetrical adaptation of several enzymes.

The similarity both in the magnitude of the adaptive increases of these five enzyme systems and in the magnitude of the net ammonia excretion after substrate loads suggests that when substrate is furnished in abundance by the administration of appropriate amino acids, these enzyme systems apparently can contribute equally to urinary ammonia. However, under normal circumstances there is a considerable variation in the concentration of precursor amino acids in plasma. In plasma, glutamine constitutes 20 to 25 per cent of the free $\alpha$-amino nitrogen $(15,28)$ and $l$-alanine and glycine, another 24 per cent $(29) ; d$-alanine is apparently absent and asparagine is present in trivial concentrations (28). The contribu-

6 The changes in enzyme activity when the chronic $\mathrm{NH}_{4} \mathrm{Cl}$ load was increased from $5 \mathrm{Gm}$. per day to higher levels were not used because the net increase in ammonia excretion after substrate at this level was negligible or small compared to the control values. On the other hand, the net increases in ammonia excretion after substrate when the subjects were maintained on 10 and $15 \mathrm{Gm}$. per day were larger and therefore were considered to reflect more accurately enzymatic alterations. 
tion to urinary ammonia of the enyme systems which are capable of adaptation may therefore vary widely because of substrate limitation.

The biological role of these enzymes, capable of adaptation, is not adequately defined. Significant activity of $l$-amino acid oxidase has been demonstrated in vitro in only the rat kidney (8). Despite its exceedingly low turnover number of 6 , it nevertheless appears to be active in vivo in the human kidney and evidence from these studies and those in the rat (16) indicate that adaptation occurs. The disparity between the in vivo and in vitro evidence of its activity may exist because the ideal conditions for demonstrating in vitro activity have not been elucidated.

More engimatic is the $d$-amino acid oxidase, an ubiquitous enzyme, found in all mammalian kidneys tested and having a high $(1,440)$ turnover number (11). The presence of a highly active enzyme without apparent substrate beclouds its physiologic role. Nonetheless, the administration of $d$-alanine to human subjects resulted in augmentation in ammonia excretion and the evidence presented indicating adaptive change during chronic acid loading bespeaks a physiologic role. Amino acid racemases, capable of interconverting $l$ and $d$ forms, have been found in microorganisms (11). Such a racemase may be present in mammalian kidney and undergo adaptive change, thereby shunting, as acid load requires, a portion of the $l$-amino acid pool into $d$-amino acid substrate for ammonia production.

In contrast to the apparent physiologic importance in the renal regulation of acid-base balance of those enzyme systems showing adaptive changes is the role of glutamic dehydrogenase, aspartic transaminase and proline oxidase for which no evidence of adaptation was found. Lotspeich and Pitts failed to find any augmentation of ammonia excretion after the infusion of glutamic acid in acidotic dogs (2). Neither proline oxidase nor aspartic transaminase directly increase ammonia production (Table I). Both, however, augment the synthesis of glutamic acid which may then be deaminated by glutamic dehydrogenase, thereby increasing ammonia production. The failure of proline or aspartic acid administration to augment ammonia excretion progressively may, therefore, indicate that either proline oxidase and aspartic transaminase do not adapt or/and that glutamic dehydrogenase does not adapt.

The inferential identification of the adaptation of a specific enzyme by the administration of its precursor amino acid implicitly assumes that the rise in ammonia excretion under such circumstances is the consequence of the effect of the administered precursor amino acid on the specific enzyme system for which it is substrate. It is conceivable, however, that the administered amino acid might be converted by a transamination reaction to another substrate that would then act upon another enzyme system which then would be responsible for the augmented ammonia excretion. This possibility seems unlikely. All transaminases including glutamine- $\alpha$-keto acid and aspargine- $\alpha$ keto acid transaminase are pyridoxal phosphate and pyridoxamine phosphate dependent $(13,28)$; yet in pyridoxine deficient rats with reduced transaminase activity (30) the renal response to acid loads is normal, ammonia excretion is high and glutaminase adaptation occurs (31). This suggests that the transaminase systems do not contribute significantly to the renal production of ammonia. Moreover, it is noteworthy that even though amino acids can be readily transaminated to glutamate and glutamate to other amino acids, nevertheless the administration of glutamate, aspartate and proline resulted in only a very small increase in ammonia excretion. In addition, the adaptation of glutaminase (16-19), glycine oxidase and amino acid oxidase (16) has been shown in vitro to follow the administration of strong acid loads. For these reasons it seems likely that the changes in ammonia excretion after the administration of a specific amino acid can be ascribed to its effect on the enzyme system for which it is substrate.

The increased urinary ammonia excretion that follows amino acid administration was invariably associated with an increase in total acid excretion $\left[\mathrm{NH}_{3}\right.$ plus $\left.\left(\mathrm{TA}-\mathrm{HCO}_{3}\right)\right]$. These findings differ from those of Orloff and Berliner (25), who failed to find any consistent increase in total acid excretion following the infusion of $d l$-alanine into dogs. The discrepancy may be related either to species difference or to the fact that their experiments, conducted during acute acidosis, were different from the present studies which were performed during chronic acidosis. 
The increased urinary $\mathrm{pH}$ that attends the increased ammonia excretion following substrate loads may be the result of either increased diffusion of ammonia from tubular cell to tubular urine thereby titrating tubular $\mathrm{H}^{+}$and permitting further $\mathrm{H}^{+}$for $\mathrm{Na}^{+}$exchange by maintaining an increased gradient from cell to urine, or it may be the result of an increased exchange of cellular ammonium ion for urinary sodium ion which otherwise would have exchanged for $\mathrm{H}^{+}$(32).

The relationship between urine $\mathrm{pH}$ and urinary ammonia that follows the chronic administration of strong acid loads of increasing magnitude contrasts sharply with the inverse relationship that prevails during acute acid loading $(33,34)$. This rise in urine $\mathrm{pH}$ with increases in chronic $\mathrm{NH}_{4} \mathrm{Cl}$ intake could result from the enhanced diffusion of ammonia from tubular cell to tubular urine caused by the high concentration gradients produced by accelerated ammonia formation. It is also possible that with increased activity of the renal ammoniaproducing enzyme systems, the exchange of $\mathrm{NH}_{4}{ }^{+}$ for $\mathrm{Na}^{+}$increases to some extent at the expense of $\mathrm{H}^{+}$for $\mathrm{Na}^{+}$exchange, resulting thereby in a rise in urine $\mathrm{pH}$. Whatever explanation is valid, one consequence of renal enzymatic adaptation is the excretion of increased amounts of ammonia at any given urine $\mathrm{pH}(19,35)$.

Evidence from the present experiments indicates that the superimposition of an acute alkalosis in a subject chronically maintained on $15 \mathrm{Gm}$. of $\mathrm{NH}_{4} \mathrm{Cl}$ per day prevents the usual increase in ammonia excretion after a substrate load and results instead in a sharp decline in ammonia excretion (Figure 8). Data concerning the effects of alkalosis upon ammonia production are conflicting. Van Slyke and associates (1) reported that the diminution in urinary ammonia excretion which attends the changing from hydrochloric acid acidosis to bicarbonate alkalosis is associated with a decreased renal utilization of glutamine $(1,9)$ and a decreased renal production of ammonia. Other evidence (36) indicates unaltered ammonia production and decreased urinary ammonia excretion associated with an acute alkalosis.

\section{SUMMARY}

One hundred twenty-five experiments were performed on five subjects maintained on chronic acid loads of increasing magnitude. Under these conditions precursor amino acids were administered and the renal ammonia producing enzymes in the human kidney inferentially identified. By comparing the magnitude of response in ammonia excretion to a fixed amino acid load at several different levels of ammonium chloride administration, those enzymes which adapt were identified. Evidence was presented indicating that, in the human kidney, glutaminase, asparaginase, glycine oxidase, $l$-amino acid oxidase and $d$-amino acid oxidase adapt to chronic acid loads whereas glutamic dehydrogenase, proline oxidase and aspartic transaminase do not.

\section{ACKNOWLEDGMENT}

The authors are indebted to Mrs. Kathleen Rencz and Mrs. Imogene Nordenbrock for technical assistance.

\section{REFERENCES}

1. Van Slyke, D. D., Phillips, R. A., Hamilton, P. B., Archibald, R. M., Futcher, P. H., and Hiller, A. Glutamine as source material of urinary ammonia. J. biol. Chem. 1943, 150, 481.

2. Lotspeich, W. D., and Pitts, R. F. The role of amino acids in the renal tubular secretion of ammonia. J. biol. Chem. 1947, 168, 611.

3. Bliss, S. Increased excretion of urinary ammonia in the dog following the intravenous injection of both natural and unnatural forms of certain amino acids. J. biol. Chem. 1941, 137, 217.

4. Kamin, H., and Handler, P. The metabolism of parenterally administered amino acids. III. Ammonia formation. J. biol. Chem. 1951, 193, 873.

5. Krebs, H. A. Metabolism of amino-acids. IV. The synthesis of glutamine from glutamic acid and ammonia, and the enzymatic hydrolysis of glutamine in animal tissues. Biochem. J. 1935, 29, 1951.

6. Ratner, S., Nocito, V., and Green, D. E. Glycine oxidase. J. biol. Chem. 1944, 152, 119.

7. Blanchard, M., Green, D. E., Nocito, V., and Ratner, $\mathrm{S}$. Isolation of 1-amino acid oxidase. J. biol. Chem. 1945, 161, 583.

8. Blanchard, M., Green, D. E., Nocito, V., and Ratner, S. 1-Amino acid oxidase of animal tissue. J. biol. Chem. 1944, 155, 421.

9. Archibald, R. M. The enzymatic determination of glutamine. J. biol. Chem. 1944, 154, 643.

10. Weil-Malherbe, H., and Krebs, H. A. Metabolism of amino-acids. V. The conversion of proline into glutamic acid in kidney. Biochem. J. 1935, 29, 2077.

11. Cohen, P. P. Nitrogen metabolism of amino acids in Chemical Pathways of Metabolism, D. M. Greenberg, Ed. New York, Academic Press Inc., 1954, vol. 2, p. 1. 
12. Zittle, C. A. Hydrolysis of acid amides and amides and amino acid amides in The Enzymes, J. B. Sumner and K. Myrbäck, Eds. New York, Academic Press Inc., 1950, vol. 1, part 2, p. 922.

13. Cohen, P. P. Transaminases in The Enzymes, J. B. Sumner and K. Myrbäck, Eds. New York, Academic Press Inc., 1950, vol. 1, part 2, p. 1040.

14. Krebs, H. A. Oxidation of amino acids in The Enzymes, J. B. Sumner and K. Myrbäck, Eds. New York, Academic Press Inc., 1950, vol. 2, part 1, p. 499.

15. Archibald, R. M. Chemical characteristics and physiological roles of glutamine. Chem. Rev. 1945, 37, 161.

16. Davies, B. M. A., and Yudkin, J. Studies in biochemical adaptation. The origin of urinary ammonia as indicated by the effect of chronic acidosis and alkalosis on some renal enzyme in the rat. Biochem. J. 1952, 52, 407.

17. Rector, F. C., Jr., Seldin, D. W., Roberts, A. D., Jr., and Copenhaver, J. H. The relation of ammonia excretion to urine pH. Amer. J. Physiol. 1954, 179, 353.

18. Leonard, E., and Orloff, J. Regulation of ammonia excretion in the rat. Amer. J. Physiol. 1955, 182, 131.

19. Rector, F. C., Jr., Seldin, D. W., and Copenhaver, J. H. The mechanism of ammonia excretion during ammonium chloride acidosis. J. clin. Invest. $1955,34,20$.

20. Conway, E. J. Microdiffusion Analysis and Volumetric Error, 3rd ed. London, C. Lockwood, 1950.

21. Wesson, L. G., Jr. Effect of temperature change on the $\mathrm{pH}$ of human urine. J. appl. Physiol. 1953, $5,619$.

22. Dawson, J., Dempsey, E., Bartter, F., Leaf, A., and Albright, F. Evidence for the presence of an amphoteric electrolyte in the urine of patients with "renal tubular acidosis." Metabolism 1953, 2, 225.

23. Peters, J. P., and Van Slyke, D. D. Quantitative Clinical Chemistry. Vol. II. Methods. Baltimore, Williams and Wilkins, 1932.
24. Hald, P. M. Determinations with flame photometer in Methods in Medical Research, M. B. Visscher, Ed. Chicago, Year Book Publishers, 1951, vol. 4, p. 79.

25. Orloff, J., and Berliner, R. W. The mechanism of the excretion of ammonia in the dog. J. clin. Invest. 1956, 35, 223.

26. Moelwyn-Hughes, E. A. Physical chemistry and chemical kinetics of enzymes in The Enzymes, J. B. Sumner and K. Myrbäck, Eds. New York, Academic Press Inc., 1950, vol. 1, part I, p. 28.

27. Sartorius, O. W., Roemmelt, J. C., and Pitts, R. F. The renal regulation of acid-base balance in man. IV. The nature of the renal compensations in ammonium chloride acidosis. J. clin. Invest. 1949, 28, 423.

28. Meister, A. Metabolism of glutamine. Physiol. Rev. 1956, 36, 103.

29. Gutman, G. E., and Alexander, B. Studies of amino acid metabolism. I. Blood glycine and alanine and their relationship to the total amino acids in normal subjects. J. biol. Chem. 1947, 168, 527.

30. Schlenk, F., and Snell, E. E. Vitamin $B_{6}$ and transamination. J. biol. Chem. 1945, 157, 425.

31. Portwood, R. M., and Madison, L. L. The role of transaminase in the renal production of ammonia. Clin. Res. 1958, 6, 288.

32. Ryberg, C. The importance of sodium ions for the excretion of ammonium and hydrogen ions in the urine. Acta physiol. scand. 1948, 15, 161.

33. Briggs, A. P. The significance of the urinary ammonia. J. Lab. clin. Med. 1942, 28, 174.

34. Gilman, A., and Brazeau, P. The role of the kidney in the regulation of acid-base metabolism. Amer. J. Med. 1953, 15, 765.

35. Pitts, R. F. Renal excretion of acid. Fed. Proc. 1948, 7, 418.

36. Poppell, J. W., Cuajunco, F., Jr., Horsley, J. S., III, Randall, H. T., and Roberts, K. E. Renal arteriovenous ammonium difference and total renal ammonium production in nomal, acidotic and alkalotic dogs. Clin. Res. Proc. 1956, 4, 137. 